\title{
Review on California Mastitis Test (CMT)
}

\section{Tesfaye $B^{*}$}

Assela Regional Animal Health Diagnostic Laboratory, Ethiopia

*Corresponding author: Tesfaye Belachew, Assela Regional Animal Health Diagnostic Laboratory, Assela, Oromiya, Ethiopia, Tel: +251933864966; Email: teyobeku@gmail.com

\section{Mini Review}

Volume 3 Issue 3

Received Date: July 24, 2018

Published Date: September 07, 2018

\section{Abstract}

The California Mastitis Test (CMT) is a quick, simple test that accurately predicts the somatic cell count of milk from individual quarters or on composite milk samples [1]. The California Mastitis Test is a simple, inexpensive, rapid screening test for mastitis. The test is based upon the amount of cellular nuclear protein present in the milk sample. Since inflammatory cells associated with mastitis are the predominant cell type present in milk the CMT reflects the SCC level quite accurately and is a reliable indicator of the severity of infection. The test is appropriate for cow-side evaluation of udder health and the procedure can be taught quickly to producers and the milking crew. With proper training test results are very repeatable among those conducting the test. It is necessary that producers also be made aware of the limitations of the CMT and the proper application of management decisions based on CMT results.

Keywords: California Mastitis Test; Milking; Leucocyte

\section{Principles CMT}

The CMT is accurate on cow's and goat's milk. Thus, the accuracy of the CMT is found three principles:

- Leucocyte (white blood cells) numbers greatly increase in number when an injury or infection affects mammary tissue.

- Leucocytes: especially, polymorphonuclear leucocytes (PMNs) have large nuclei (DNA) compared to other cells or bacteria in milk.

- Leucocyte cell walls are mainly lipid (fat).

\section{How the CMT Works}

CMT reagent is a detergent with a $\mathrm{pH}$ indicator added (reason for purplish color). When milk and CMT reagent are mixed in equal amounts, the CMT reagent dissolves or disrupts the outer cell wall and the nuclear cell wall of any leucocyte, which are primarily fat (detergent dissolves fat). DNA is now released from the nuclei. DNA will string or gel together to form a stringy mass. As the number of leucocytes increase in a quarter, the amount of gel formation will increase in a linear fashion [1].

\section{Equipment}

Milk samples from each quarter are collected in a clean CMT Paddle. The CMT paddle has four shallow cups marked A, B, C, and D to help identify the individual quarter from which the milk was obtained. The CMT Solution should be reconstituted according to package instructions (Figure 1). 


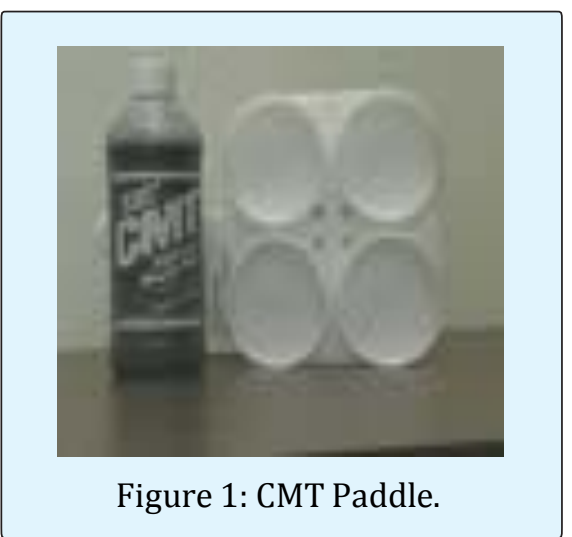

Figure 1: CMT Paddle.

\section{CMT Procedure}

Step 1: Take about 1 teaspoon (2 cc) milk from each quarter. This is the amount of milk that would be left in the cups if the CMT Paddle were held nearly vertical.

Step 2: Add an equal amount of CMT solution to each cup in the paddle.

Step 3: Rotate the CMT Paddle in a circular motion to thoroughly mix the contents. Do not mix more than 10 seconds.

Step 4: "Read" the test quickly. Visible reaction disintegrates after about 20 seconds.

\section{Reading CMT}

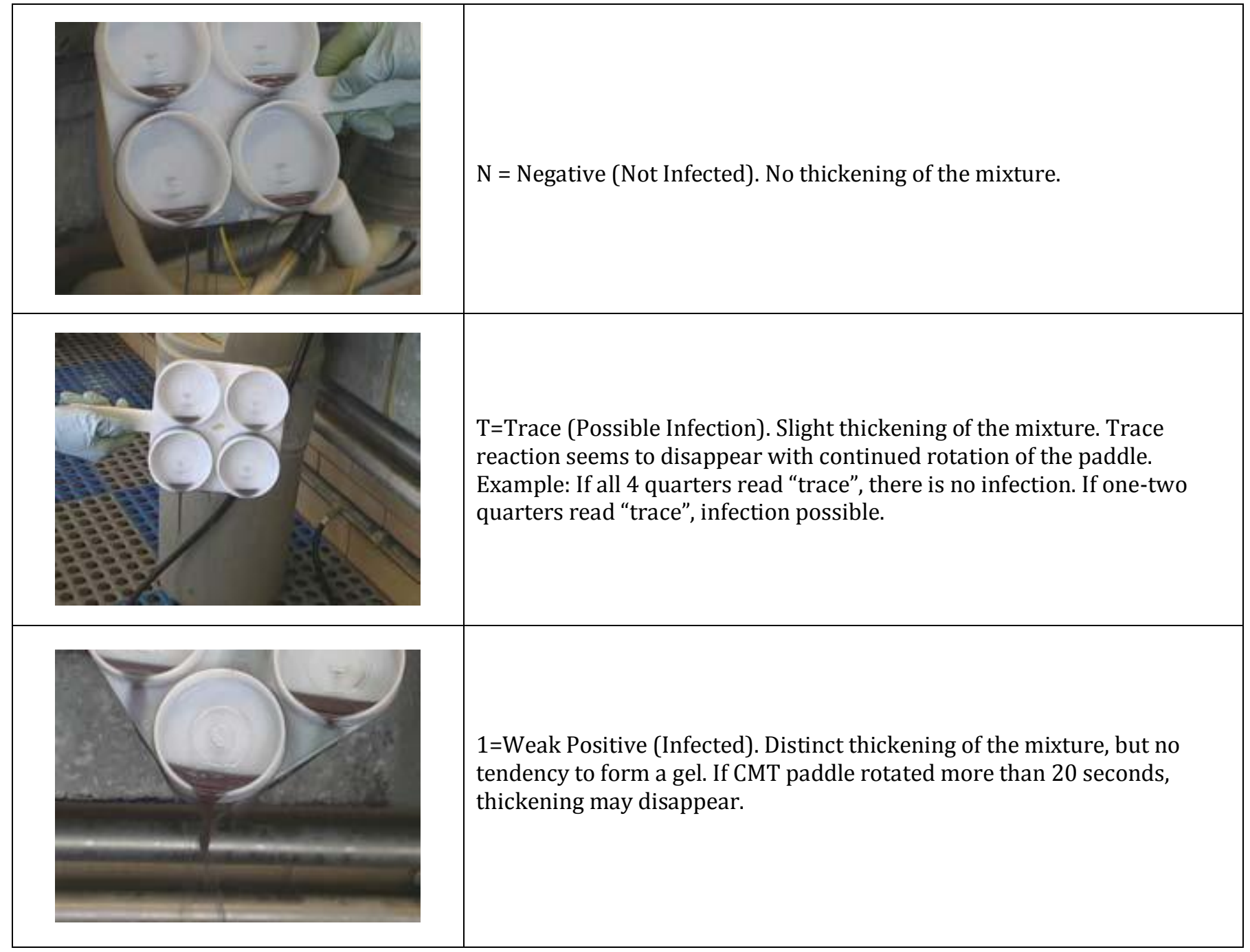




\section{Open Access Journal of Veterinary Science \& Research}

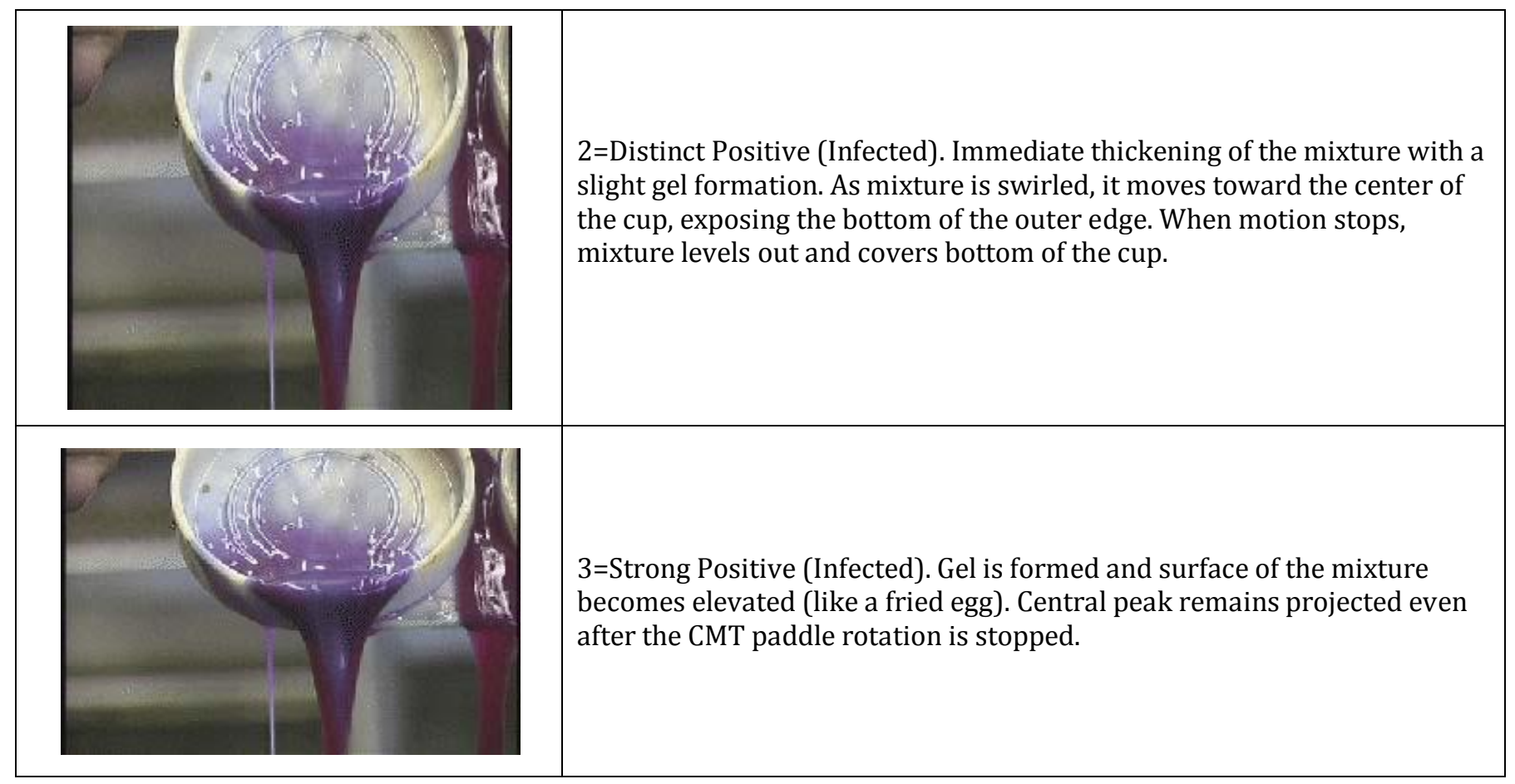

Figure 2: Reading CMT.

\section{Interpretation of CMT Scores}

CMT scores are directly related to average somatic cell counts. The following table 1 shows how they are related

$[2,3]$. Any reaction of $\mathrm{T}$ (trace) or higher indicates that the quarter has subclinical mastitis.

\begin{tabular}{|c|c|c|}
\hline CMT Score & Somatic Cell Range & Interpretation \\
\hline N (Negative) & $0-200,000$ & Healthy Quarter \\
\hline T (Trace) & $200,000-400,000$ & Subclinical Mastitis \\
\hline 1 & $400,000-1,200,000$ & Subclinical Mastitis \\
\hline 2 & $1,200,000-5,000,000$ & Serious Mastitis Infection \\
\hline 3 & Over $5,000,000$ & Serious Mastitis Infection \\
\hline
\end{tabular}

Table 1: CMT Scores.

\section{References}

1. Mellenerger R (2001) California Mastitis Test (CMT) An Invaluable Tool for Managing Mastitis. Department of Animal Sciences, Michigan State University, USA, Pp: 9.
2. Mellenberger R (2000) California Mastitis Test (CMT) Fact Sheet. Dept. of Animal Sciences, Michigan State University, USA.

3. Fikadu K (2005) Standard Veterinary Laboratory Diagnostic Manual, Bacteriology. Ministry of Agriculture of Ethiopia 2: 1-175. 